\title{
Development of the World Englishes Instructional Model to Enhance Students' Listening Comprehension toward Varieties of English
}

\author{
Navarat Boonsamritphol ${ }^{1} \&$ Sorabud Rungrojsuwan ${ }^{1}$ \\ ${ }^{1}$ English for Professional Development Program, School of Liberal Arts, Mae Fah Luang University, Chiangrai, \\ Thailand \\ Correspondence: Navarat Boonsamritphol, English for Professional Development Program, School of Liberal \\ Arts, Mae Fah Luang University, Chiangrai, Thailand.
}

Received: August 24, 2021

Accepted: September 17, 2021

Online Published: September 22, 2021

doi: $10.5539 /$ elt.v14n10p49

URL: https://doi.org/10.5539/elt.v14n10p49

\begin{abstract}
This research aimed to develop the World Englishes instructional model to enhance students' listening comprehension of varieties of English. The student's needs analysis was conducted in the first step of the study to gather data concerning the needs, problems, and opinions on teaching and learning English listening. Thirty students participated in the needs assessment questionnaire data collection by answering alternative and open-ended questions. Three experts evaluated the model's quality was evaluated in terms of the consistency of its components and the appropriateness of its component descriptions. Based on the results of the needs assessment questionnaire and expert evaluation, three main elements - students' needs analysis, theoretical concepts, and course components of the World Englishes instructional model-were developed as instructional components comprising course objectives, course contents, media and materials, teaching strategies, and learning activities, as presented in this paper.
\end{abstract}

Keywords: World Englishes (WEs), English as a lingua franca (ELF), intelligibility, comprehensibility, listening comprehension

\section{Introduction}

English now plays a more important role in Thailand than in the past as the lingua franca for communication in the ASEAN community and other countries around the world (Darasawnag et al., 2015; Piamsai, 2017). The Thai population is now working and communicating with increasing numbers of English users from different countries. Thai students require knowledge of English as a second language to communicate with people from other nations who also converse in English (Todd, 2006).

In Thailand, English as a foreign language (EFL) is taught in educational institutions. However, EFL teaching in higher education limits exposure to other varieties of English. The Thai educational system focuses on a native speaker model, and English teachers mostly expose their students to British or American English in the classroom. This results in many Thai students having difficulty in understanding non-native English speakers when they use English in real situations (Kongkerd, 2013; White et al., 2016). Therefore, English teachers should encourage students to learn the version of English that is most suitable for communication purposes. New instructional models are required to prepare lessons for Thai EFL students.

To be able to communicate with English users from different countries, English language students must be exposed to diverse varieties of English. Two broad approaches were used to select which English varieties should be studied. Educators must weigh several factors that are universally valid in English language teaching contexts. These factors were divided into two dichotomies: (a) practical concerns related to what happens in the classroom, and (b) ideological concerns related to the wider society, depending on the context and purpose of the English usage (Seargeant, 2012, p. 66).

Previous studies in the field of EFL teaching focused on standardized English (American or British English) with limited exposure to the outer circle and expanding circle Englishes (Matsuda, 2000; Pederson, 2012; Kongkerd, 2013; Sung, 2015; Fang \& Ren, 2018). Implementation of WEs also focused on students' attitudes and awareness regarding the understanding and intelligibility of the English variations. Only a few studies paid detailed attention to the conceptual implementation of WEs and exposure to different varieties of English as part of students' 
listening comprehension, particularly regarding the phonological features corresponding to intelligibility and comprehensibility levels.

Therefore, here, to enhance Thai students' listening comprehension toward different varieties of English, the World Englishes (WEs) instructional model was developed. This model focused on enhancing the exposure to varieties of English related to basic comprehension based on levels of intelligibility (word recognition) and comprehensibility (meaning understanding). The proposed model did not aim to replace native norms but rather to add varieties of English to enrich students' listening comprehension.

\subsection{Research Objectives}

1) To investigate students' needs regarding the WEs instructional model.

2) To examine the quality of the WEs instructional model in enhancing students' listening comprehension regarding varieties of English.

\subsection{Research Questions}

1) What are students' needs regarding the WEs instructional model?

2) What are the results of quality examination of the WEs instructional model in enhancing students' listening comprehension regarding varieties of English?

\section{Literature Review}

\subsection{WEs and English as a Lingua Franca}

World Englishes (WEs) and English as a lingua franca (ELF) have some common ground as the notion of the pluricentricity of English and the ideology that language changes and adapts to a new environment (Cogo, 2012). Jenkins (2015) pointed out that the WEs paradigm and ELF theories are related to each other, and should be included in global Englishes as holistic terms. Both approaches view English as the main option for interaction between people from different first language (L1) backgrounds, and English is considered as a lingua franca under the umbrella term of the WEs paradigm (Kachru, 1985, 1992).

Several pedagogical models have been used to describe the global spread of English (Crystal, 1988). The Kachru (1985) model presented the sociolinguistic functions of English around the world using three concentric inner, outer, and expanding circles. However, this model is not suitable for the current use and function of English. Various scholars (e.g. Rampton, 1990; Seidlhofer, 2002; Graddol, 2006; Kirkpatrick, 2007; Dröschel, 2011; Jenkins, 2015) argued that Kachru's model was outdated and limited in describing the role and function of English in the real world. Alternative models and descriptions of the spread of English were proposed to improve Kachru's model to suit real circumstances (e.g. McArthur, 1998; Modiano, 1999; Graddol, 2006; Yano, 2009). Later, Yano'scylindrical model (Figure 1) was constructed to represent the contextualization of English users' speech within a variety of cylinders. This model attempted to make WEs more democratic and dynamic rather than static by focusing on all varieties. Yano designed the cylindrical model to help teachers, educators and students recognize the real situation of the linguistic landscape of WEs (Yano, 2009). Models of pedagogical methods and materials have changed to adapt to new challenges that WEs provide (Jenkins, 2015).

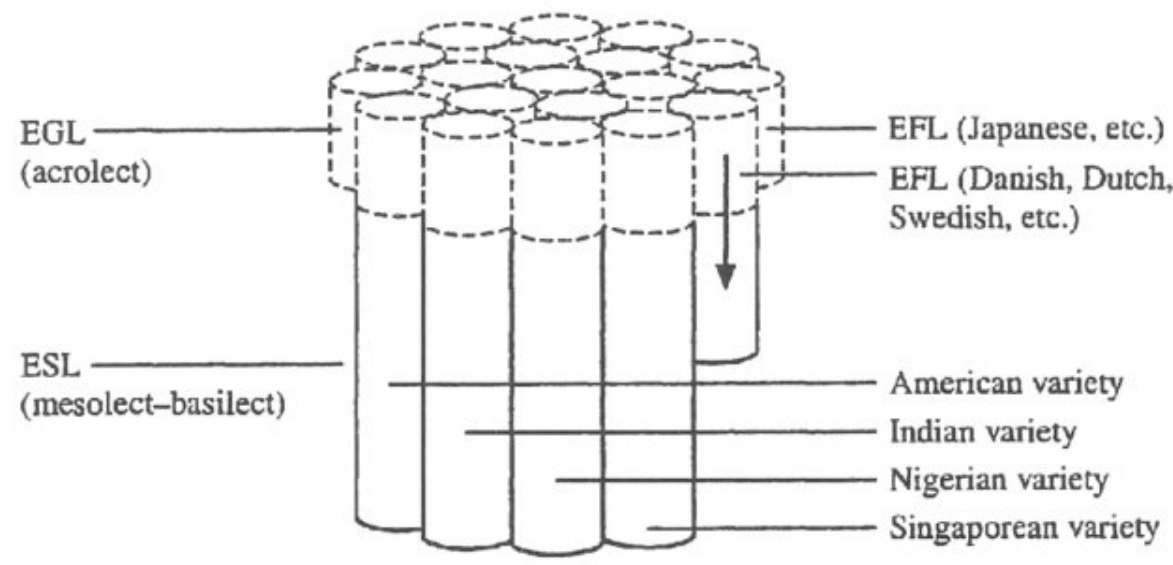

Figure 1. Yano's Cylindrical Model 
Previous studies showed that implementing WEs and ELF concepts in the classroom helped improve students' recognition and awareness of English language variations (Ates et al., 2015; Chang, 2015; Lu \& Buripakdi, 2020). Boonsuk \& Ambele (2021) suggested that the goals and curricula of teaching and learning should be updated, particularly for English used in an ELF context, to implement appropriate English use in the classroom rather than focusing on native varieties of English, while Matsuda (2003) suggested the need to prepare students to use English in the future by including both non-native and native speakers from different parts of the world.

Based on the context and communicative purpose requirements, students should communicate internationally with English users in real situations, especially those from ASEAN countries. A selection of WEs models was analyzed and synthesized. The Yano (2009) model relates to English use in international contexts and circumstances (Jenkins, 2015). This model emphasizes all varieties of English used in real situations. Moreover, the selection of English varieties is considered in terms of the teaching context and students' communicative purpose as (a) the varieties of English and skills needed to be presented in class, and (b) the varieties of English and skills that students need to learn and use outside class (Seargeant, 2012).

\subsection{ELF Phonological Features and Accommodation Skills}

The increasing use of ELF around the world has changed the sociolinguistic landscape (Galloway \& Rose, 2014). ELF often has no native speakers who occupy a minority position in ELF communication, contrasting with the EFL context used as a foreign language based on a native yardstick (Jenkins, 2000). Based on ELF interaction, Jenkins (2000) proposed a phonological core for the preservation of mutual intelligibility. This emerged from the data of Interlanguage Talk (ILT). Jenkins introduced a list of phonological features that produced the maximum communication breakdown between interlocutors in an ELF context. The two fundamental terms of the ELF core are segmental and suprasegmental. These can be divided into five features as shown in Table 1.

Table 1. The Lingua Franca Core

\section{The Lingua Franca Core}

\begin{tabular}{ll}
\hline 1. Consonantal inventory & $\begin{array}{l}\text { All sounds except } / \theta /, / \mathrm{d} / \text { and } / \mathrm{t} / ; \text { most substitutions of } / \theta /, / \mathrm{d} /, \text { and } / \mathrm{t} / \\
\text { are permissible }\end{array}$ \\
2. Phonetic requirements & $\begin{array}{l}\text { Aspiration following the fortis plosive } / \mathrm{p} / / \mathrm{t} / / \mathrm{k} / \text { and fortis and lenis } \\
\text { differential effects on preceding vowel length }\end{array}$ \\
3. Consonant clusters & $\begin{array}{l}\text { Medial and final clusters simplified according to } \mathrm{L} 1 \text { rules of elision } \\
\text { Maintenance of long-short vowel length contrast }\end{array}$ \\
4. Vowel quantity & Production, placement, and division of speech stream into word groups
\end{tabular}

Kirkpatrick \& Sussex (2012) pointed out that the linguistic goals of English language pedagogy should be redefined in a lingua franca curriculum and not focus only on native norms and traditional second language acquisition, whereas Reed \& Levis (2019) indicated that an ELF approach of pronunciation teaching should include the two main tenets of ability in lingua franca core and accommodation skills.

The strategy used to facilitate students' ability to adjust and be successful in ELF interactional contexts is called accommodation skills. These skills refer to the terms of speakers' and listeners' roles that are called productive and receptive skills (Jenkins, 2000; Walker, 2010). According to Walker (2010), speakers use productive skills to enable their interlocutors to understand them more easily, while listeners use receptive skills to engage in ELF communication with an open mind, thereby tolerating and accepting differences. Students learn these strategies to adjust, understand and tolerate their English interlocutors to increase communicative flexibility and respect English language variations. Richard and Wu (2006) tested the perception of undergraduate students' accents using a receptive approach. Students listened to a passage read by four speakers with different accents: American English, British English, Chinese English and Mexican English. The researchers found that the students could hear, analyze, and compare key features of accent variation. The receptive approach addressed both intelligibility and listening comprehension to increase flexible communication and respect for accent variations.

Based on the study's purpose, receptive phonological accommodation was adapted in teaching and learning activities. Students learned and practiced their receptive accommodation to improve their ability to understand English speakers with different phonological features. Students listened to a passage, compared the different phonological features of English varieties, discussed and shared ideas, and read a script aloud to increase their familiarity and comprehension by focusing on phonological features (Walker, 2015). Various available websites are useful for teaching and learning activities and for students to practice receptive phonological accommodation such as the International Dialects of English Archive, My English Voice, and YouTube. 


\subsection{Intelligibility and Listening Comprehension}

With the rapid spread of different varieties of English, a key component of international interaction is intelligibility (Seargeant, 2012). Smith and Nelson (1985) clarified understanding into three levels. First, intelligibility refers to word and utterance recognition. Second, comprehensibility refers to word and utterance understanding. Third, interpretability (the highest level) refers to perception of the speaker's intentions. Listening comprehension refers to decoding processes that listeners apply to achieve understanding. The decoding process begins with the smallest sound elements of the target language, such as phonemes and syllables, and then progresses towords, phrases, sentences, and meanings combined with external information such as world knowledge, personal experiences, or previous knowledge (Rost, 2002; Field, 2008).

White (2016) examined the issues and problems of EFL students coping with unintelligible speech. The students were exposed to various accents at different frequency levels. Test results showed that familiarity with an accent assisted listener comprehension, while exposure to unfamiliar accents helped students improve their listening comprehension. Cheng (2018) suggested that real-world exposure to varieties of English was necessary for students' success in accommodating unfamiliar English accents, while Kim (2017) concluded that gaining experience with different second language (L2) English varieties facilitated listener comprehension. Kang (2010) suggested that in an ELT classroom the teacher should not consider only a single model for student exposure; rather, teachers should encourage their students to improve comprehension of many varieties of WEs.

Consequently, listening comprehension at two levels was considered, based on distinguishing or perceiving speech as speech intelligibility (word recognition) and speech comprehensibility (meaning understanding) (Smith \& Nelson, 1985). These two levels were interrelated with students' listening comprehension (listening for details, listening for the main idea, and listening for understanding) of varieties of English. Intelligibility level (word recognition) refers to the phonological features that the students need to recognize in the English words. For instance, at the first stage, students can decode, starting from the sound elements with phonemes $/ p /, / t /, / k /$, then progress towards such as "pin," "tin," and "cap," and finally connect to utterances. Comprehensibility level (meaning understanding) refers to students' ability to understand the basic meaning by decoding sounds from the first stage and progressing to the second stage in terms of comprehensibility to understand the utterance meanings. In this context, when students recognize the word please, they normally understand it as a request or directive, basically related to a polite signal (Nelson, 2011).

\subsection{Principles of Instructional Model Design}

Several instructional models have been designed for effective teaching and learning by various educators such as the ADDIE model (Gagné et al., 2005), DC model (Dick et al., 2001) and MRK model (Morrison et al., 2011).

Instructional design and development of the ADDIE model are the most basic concepts. This instructional system design (ISD) process contains five components: analysis, design, development, implementation, and evaluation. Each of the five stages has sub-steps that receive more or less emphasis in other models of the ISD process. Probably the best known of all instructional design models is the Dick and Carey model (DC) (2001). This model uses the systems approach for designing effective instruction. The model design includes determining the instructional goal, conducting instructional analysis, analyzing students and contexts, writing performance objectives, developing assessment instruments, developing an instructional strategy, creating and choosing instructional materials, designing and conducting a formative evaluation of instruction, revising instruction, and designing and conducting a summative evaluation.

Another course design called MRK Instructional Design was established by Morrison et al. (2011). It presents a holistic approach to cyclical instructional design and allows the designers to choose where to start within the process elements. The instructional processes consist of instructional problems (needs), learner characteristics, task analysis, instructional objectives, content sequencing, instructional strategies, message design, instruction development, and instrument evaluation. Course designers and developers should refer to instructional design models and techniques and follow step-by-step procedures to ensure that standard-quality instruction is created (Dick et al., 2009). The instructional design process should start from students' problems and needs and designers should identify both terms based on teaching contexts (Morrison et al., 2011). The designer should also analyze students' proficiency, purpose, preference, or attitudes because this term is necessary for constructing effective instruction (Dick et al., 2001).

Based on the analysis and synthesis of these instructional design and development models, the instructional model comprised ten components: analyzing learning needs, considering students and contexts, formulating objectives, designing course contents, determining teaching media and materials, considering teaching strategies, 
designing learning activities, implementing the instructional model, evaluating the instructional model, and summarizing and revising the instructional model.

\section{Methodology}

\subsection{Participants}

For needs analysis, the study participants comprised an intact group of 30 second-year civil engineering students taking the English for Everyday Communication course at Rajamangala University of Technology Lanna Chiangrai, and for instructional model evaluation, three experts.

\subsection{Research Instruments}

\subsubsection{Needs Assessment Questionnaire}

The needs assessment questionnaire was conducted in the first step of the study to gather data concerning students' needs, problems, and opinions on teaching and learning in the course to identify the requirements for developing the instructional model. The questionnaire asked students to explain their needs, problems, suggestions, and expectations in teaching and learning English listening. Information was gathered by reviewing existing theories and related studies. The questionnaire was adapted from Fraenkel and Wallen (2003), Dawilai (2017), and Piamsai (2017). The scaled questions were answered using a 5-point Likert scale. The last part contained open-ended questions to elicit opinions and detailed information from the students. The needs assessment questionnaire had three main parts. Part 1 comprised students' learning needs with sub-topics consisting of (1) course content, (2) media and materials, (3) teaching strategies, and (4) learning activities based on the synthesis of instructional design theories (Dick et al., 2001; Gagné et al., 2005; Morrison et al., 2011). Part 2 comprised students' problems in English listening comprehension. Part 3 included suggestions and expectations regarding class instruction as open-ended questions to allow students to express their opinions on the course. The questionnaire items were designed in both Thai and English to facilitate students' comprehension. In addition, the questionnaire was initially evaluated for content validity by three experts in the fields of English teaching, language assessment, and English listening teaching. The experts' evaluation of the item-objective congruence (IOC) results scored the overall content validity of the needs assessment questionnaire at 0.83 . Moreover, the questionnaire was tested with 30 students who were not in the target group, with analysis of reliability calculated using Cronbach's alpha, which gave reliability value of 0.88 , interpreted as reliable.

\subsubsection{The WEs Instructional Model}

The model was developed based on students' needs and theories related to the WEs concept, ELF phonological features, intelligibility and listening comprehension, and accommodation skills. Model design and development were derived from the analysis and synthesis of three models for instructional design as the ADDIE model, DC model, and MRK model (Dick et al., 2001; Gagné et al., 2005; Morrison et al., 2011). The model consisted of ten components, with each component related to the others as (1) analyzing students' needs, (2) considering students and contexts, (3) formulating objectives, (4) designing course contents, (5) determining teaching media and materials, (6) considering teaching strategies, (7) designing learning activities, (8) implementing the instructional model, (9) evaluating the instructional model, and (10) summarizing and revising the instructional model.

\subsection{Data Collection}

The data collection proceeded as follows. In the first step, 30 students completed the needs assessment questionnaire for analysis and identification of the problems and requirements for developing the instructional model. Then, the WEs instructional model was evaluated for consistency and appropriateness of the models' components descriptors by three experts in English language, instruction, and curriculum.

\subsection{Research Procedures and Data Analysis}

\subsubsection{Research Procedures}

The six procedures, based on the synthesis of instructional design theories (Dick et al., 2001; Gagné et al., 2005; Morrison et al., 2011), are presented below.

\section{1) Analyzing Students' Needs}

The needs assessment questionnaire was used as a research instrument to analyze students' needs, problems, suggestions, and expectations for teaching and learning English listening to design an appropriate instructional model. 


\section{2) Considering Students and Contexts}

Students' proficiencies and communicative purposes and contexts were considered to design appropriate instructions. Students' English listening proficiency, varieties of English and skills that should be presented in class, and varieties of English and skills that students needed to learn and use outside the class were determined.

3) Synthesizing Related Theories and Concepts

Four main issues of related theoretical concepts, including World English concepts, ELF phonological features, intelligibility and comprehension, and accommodation skills were analyzed and synthesized.

4) Constructing the WEs Instructional Model Development

The specific information of students' needs mentioned above, as well as theoretical concepts, were used as the basis for the WEs instructional model development.

5) Evaluating the Instructional Model

The instructional model was evaluated by three experts in the fields of English language, curriculum, and instruction.

6) Summarizing and Revising the Instructional Model

Before implementation, the instructional model was summarized and revised based on the experts' comments and suggestions.

\subsubsection{Data Analysis}

\section{1) Needs Assessment Questionnaire}

The results of the needs assessment questionnaire were calculated using mean scores, standard deviation (S.D.), and content analysis and were used to analyze data concerning the students' needs, problems, expectations, and suggestions on teaching and learning to listen in English. The results of the students' needs assessment were based on a five-point Likert scale, with the criteria (Srisa-ard, 2002) as follows:

$$
\begin{array}{ll}
4.51-5.00 & \text { strongly agree } \\
3.51-4.50 & \text { agree } \\
2.51-3.50 & \text { neutral } \\
1.51-2.50 & \text { disagree } \\
1.00-1.50 & \text { strongly disagree }
\end{array}
$$

Content analysis was used to analyze data collected from the open-ended questions. Results of the students' needs analysis were interpreted and transferred into the course content, media and materials, teaching strategies, and learning activities.

2) Evaluation Form Used for the Instructional Model

The IOC value was used to analyze data from the evaluation forms collected from the three experts. Components obtaining a score of 0.5 or higher were reserved, while those obtaining a score lower than 0.50 were revised (Harrison, 1983). The criteria used to interpret the results were as follows:

\section{$0.50-1.00$ the component is appropriate}

$\leqslant 0.49$ the component is inappropriate

\section{Results}

\subsection{The Findings of Needs Assessment Questionnaire}

Table 2. Findings of Needs Assessment Questionnaire, Part 1

\begin{tabular}{lllll}
\hline No. & Course contents & Mean & S.D. & Interpretation \\
\hline 1. & The course content should be well organized and interesting & 3.57 & 0.59 & agree \\
2. & $\begin{array}{l}\text { The difficulty level of the course content should be appropriate for } \\
\text { my English proficiency }\end{array}$ & 3.51 & 0.55 & agree \\
& $\begin{array}{l}\text { The difficulty level of the assignment should be appropriate for my } \\
\text { English proficiency }\end{array}$ & 3.45 & 0.59 & neutral \\
Total & 3.51 & 0.31 & \\
\hline
\end{tabular}




\begin{tabular}{lllll}
\hline \multicolumn{1}{l}{ Media and materials } & & & \\
\hline 4. & I prefer to study English listening using audio & 3.45 & 1.01 & neutral \\
5. & I prefer to study English listening using technology and equipment & 3.25 & 1.12 & neutral \\
6. & I prefer to study English listening using visuals and video clips & 3.51 & 1.08 & agree \\
7. & I prefer to study English listening using text books & 3.21 & 1.12 & neutral \\
& Total & 3.36 & 0.58 & \\
\hline & Teaching strategies & & & \\
\hline 8. & The teacher should provide a listening introduction before listening & 3.40 & 0.59 & neutral \\
& and doing the activity & & & \\
9. & The teacher's teaching strategy should assist the students to & 3.60 & 0.54 & agree \\
& understand the lessons easily & & & \\
10. & Presenting the objectives of the lesson, a topic, and materials before & 3.30 & 0.69 & neutral \\
& learning is important & & & \\
11. & Discussion after finishing a task is helpful & 3.51 & 0.63 & agree \\
12. & Practicing outside class through homework after learning in class is & 3.37 & 0.66 & neutral \\
& helpful & & & \\
& Total & 3.44 & 0.28 & \\
\hline & Learning activities & & & \\
\hline 13. & Pair work & 3.60 & 0.98 & agree \\
14. & Group work & 3.88 & 1.06 & agree \\
15. & Class discussion & 3.51 & 1.08 & agree \\
16. & Individual work & 3.23 & 0.91 & neutral \\
17. & Group presentation & 3.08 & 1.22 & neutral \\
& Total & 3.46 & 0.40 & \\
\hline
\end{tabular}

Findings of Needs Assessment Questionnaire, Part 2

\begin{tabular}{lllll}
\hline No. & Problems in English Listening & Mean & S.D. & Interpretation \\
\hline 18. & Unable to recognize words and utterances in a listening passage & 4.03 & 1.14 & agree \\
19. & $\begin{array}{l}\text { Unable to understand the meanings of words and utterances in a } \\
\text { listening passage }\end{array}$ & 3.68 & 0.99 & agree \\
20. & $\begin{array}{l}\text { Having trouble understanding the main idea of listening (i.e., } \\
\text { what is being talked about) }\end{array}$ & 1.16 & neutral \\
21. & $\begin{array}{l}\text { Lack of familiarity in understanding foreigners' accents (i.e., } \\
\text { their accents or pronunciation are different from what I am } \\
\text { familiar with) }\end{array}$ & 0.90 & agree \\
22. & & 3.30 & 1.01 & neutral \\
23e speakers talk very fast & $\begin{array}{l}\text { More than two persons in conversation (i.e., in group } \\
\text { discussions) } \\
\text { Total }\end{array}$ & 3.23 & 0.99 & neutral \\
\hline
\end{tabular}

In Part 1, the students' needs analysis results indicated that most students agreed that the course content should be well organized and interesting $(\overline{\mathrm{x}}=3.57)$ and the difficulty level of the course content should be appropriate for their English proficiency $(\overline{\mathrm{x}}=3.51)$. Course contents considered in terms of topic, varieties of English and phonological features were organized and planned each week appropriately. Moreover, the difficulty level of the course contents and assignments was designed to suit students' English proficiency levels (CEFR B1). For instructional media and materials, most students preferred to study English through visuals and video clips $(\overline{\mathrm{x}}=$ 3.51). Thus, recorded audio and video clips were selected as relevant to the students' needs. In terms of teaching 
strategies, most students agreed that the strategies should help them understand the lessons easily $(\overline{\mathrm{x}}=3.60)$, and, following, that discussion after finishing a task is helpful $(\overline{\mathrm{x}}=3.51)$. The teaching strategies and procedures were considered and applied in the instruction. In the section on learning activities, most students preferred to do activities as group work $(\overline{\mathrm{x}}=3.88)$, followed by pair work $(\overline{\mathrm{x}}=3.60)$, and class discussion $(\overline{\mathrm{x}}=3.51)$. The activities were considered and designed to be related to students' needs in group work, pair work, and class discussion.

Findings from listening problems in Part 2 suggested that most students had problems with recognizing words and utterances $(\overline{\mathrm{x}}=4.03)$ and comprehending meaning in a listening passage $(\overline{\mathrm{x}}=3.68)$. Students were not familiar with foreigners' English accents $(\overline{\mathrm{x}}=3.55)$. Therefore, the course objectives were considered sufficiently relevant to students' problems to enhance listening improvement.

In Part 3, the open-ended questions allowed students to make useful suggestions regarding course contents and teaching strategy. The instructional model was considered and designed related to students' suggestions and expectations. The students suggested that class discussion should be provided after learning for both students and the teacher to discuss and share ideas.

"I would like to discuss and share ideas with teachers and friends because I want to review and improve my English after learning and completing assignments in class" (Student No. 30).

For learning activities, students were happy to study and do activities as group work and pair work:

"I like to work with my friend in pair work and group work because I can share ideas with my friend" (Student No. 5).

Moreover, students suggested that media and materials should be included as authentic audio clips:

"Listening contents should provide video clips with English speakers to practice listening in an interesting way instead of only using the CD or the textbook" (Student No. 16).

\subsubsection{The Experts' Evaluation of the Instructional Model}

For two iterations, three experts in the fields of English language, curriculum, and instruction examined the WEs instructional model for quality. In the first round, the experts commented on the open-ended form to identify weaknesses in the instructional model and suggest improvements. In the second round, they evaluated two aspects of the instructional model: the consistency of the model components and the appropriateness of the descriptions of each component using IOC.

In accordance with the experts' evaluation in the first round, the model was improved as detailed below.

\section{Component 2: Considering student and context}

Instructional design must consider both students and context. To develop the WEs instructional model, the experts suggested that this component should consider students' proficiencies, communicative purposes, and context to design appropriate instructions. Based on the experts' comments, students' proficiencies with consideration of communicative purposes and contexts were included.

\section{Component 6: Considering teaching strategies}

The experts suggested that students' reflective thinking and understanding should be included in this stage, with discussion activities added in the third stage of listening learning processes (post-listening). The teacher should hold class discussions to explain more about the lesson (e.g., some points that students do not understand), and discuss and share ideas.

\section{Component 7: Designing learning activities}

The four theoretical concepts should be integrated and highlighted in teaching and learning instructions and activities (see Appendix A).

\section{Component 8: Implementing the instructional model}

The concept of WEs and ELF should initially be presented. Orientation in the instructional model implementation should be conducted to enhance understanding. The eighth component was revised by orienting students to the instructional model implementation by providing them with a comprehensive understanding of WEs and ELF concepts before starting the course.

The WEs instructional model was evaluated in the first round and revised based on the experts' suggestions and comments before evaluation in the second round by the same group of experts. The mean score of model component consistency was 0.86 , and no component had low consistency. The mean scores for analyzing 
students' needs, formulating objectives, designing course contents, designing learning activities, evaluating the instructional model, and summarizing and revising the instructional model were 1.00 , while the scores for the other four components - considering students and contexts, determining teaching media and materials, considering teaching strategies, and implementing the instructional model-were 0.66 . Thus, based on the evaluation of the experts, all components of the WEs instructional model were consistent. For appropriateness of the description of each component, results gave a total mean score of 0.83 at an appropriate level. The mean rating of each component description ranged from 0.66 to 1.00 . This showed that the descriptions of all components of the model were appropriate, as shown in Table 3.

Table 3. Experts' Evaluation of the Instructional Model

\begin{tabular}{lllll}
\hline $\begin{array}{l}\text { Components of the World Englishes } \\
\text { instructional model }\end{array}$ & \multicolumn{2}{l}{$\begin{array}{l}\text { Consistency of the } \\
\text { components }\end{array}$} & $\begin{array}{l}\text { Appropriateness of the } \\
\text { component descriptions }\end{array}$ \\
\hline & $\overline{\mathrm{x}}$ & Meaning & $\overline{\mathrm{x}}$ & Meaning \\
\hline 1. Analyzing students' needs & 1.00 & consistent & 0.66 & appropriate \\
2. Considering students and contexts & 0.66 & consistent & 0.66 & appropriate \\
3. Formulating objectives & 1.00 & consistent & 1.00 & appropriate \\
4. Designing course contents & 1.00 & consistent & 1.00 & appropriate \\
5. Determining teaching media and materials & 0.66 & consistent & 0.66 & appropriate \\
6. Considering teaching strategies & 0.66 & consistent & 0.66 & appropriate \\
7. Designing learning activities & 1.00 & consistent & 0.66 & appropriate \\
8. Implementing the instructional model & 0.66 & consistent & 1.00 & appropriate \\
9. Evaluating the instructional model & 1.00 & consistent & 1.00 & appropriate \\
10. Summarizing and revising the instructional & 1.00 & consistent & 1.00 & appropriate \\
model & & & & \\
\hline Total & 0.86 & consistent & 0.83 & appropriate \\
\hline
\end{tabular}

Based on the results of the students' needs analysis and instructional model evaluation, three main components were identified for developing the WEs instructional model as shown in Figure 2. 


\begin{tabular}{|c|c|}
\hline $\begin{array}{l}\text { The Findings } \\
\quad \text { Students' needs analvsis } \\
\text { 1. Students' needs: } \\
\text { 1) Course contents } \\
\text { 2) Media and materials } \\
\text { 3) Teaching strategies } \\
\text { 4) Learning activities } \\
\text { 2. Students' listening problems } \\
\text { 1) The cause of listening comprehension } \\
\text { problems } \\
\text { 3. Students' suggestions and } \\
\text { expectations: } \\
\text { 1) Course contents } \\
\text { 2) Media and materials } \\
\text { 3) Teaching strategies } \\
\text { 4) Learning activities }\end{array}$ & $\begin{array}{l}\text { The World Englishes Instructional Model } \\
\text { Students' needs analysis }\end{array}$ \\
\hline $\begin{array}{l}\quad \text { Theoretical concepts } \\
\text { 1. The World Englishes model: } \\
\text { 1) Yano's Cylindrical Model, which } \\
\text { deeply represents the contextualization of } \\
\text { English use dynamically and } \\
\text { appropriately in an ELF context. } \\
\text { (Yano, 2009) } \\
\text { 2. ELF phonological features: } \\
\text { 1) Consonants } \\
\text { 2) Phonetic requirements } \\
\text { 3) Consonant clusters } \\
\text { 4) Vowel quantity } \\
\text { 5) Nuclear stress } \\
\text { (Jenkins, 2000) } \\
\text { 3. Intelligibility and Comprehension: } \\
\text { 1) Intelligibility level } \\
\text { 2) Comprehensibility level } \\
\text { (Smith \& Nelson, 1985) } \\
\text { 4. The receptive accommodation: } \\
\text { Students' flexibility and tolerance skills } \\
\text { toward varieties of English } \\
\text { (Walker, 2010) }\end{array}$ & $\begin{array}{l}\text { 1. Varieties of English: } \\
\text { 1) Chinese English } \\
\text { 2) Indonesian English } \\
\text { 3) Singaporean English } \\
\text { 4) Philippine English } \\
\text { 2. ELF phonological features (segmental and suprasegmental): } \\
\text { 1) Consonant replacement } \\
\text { 2) p, t, k unaspirated effect } \\
\text { 3) Consonant cluster simplification } \\
\text { 4) Vowel length contrast } \\
\text { 5) Specific word stress } \\
\text { 3. Intelligibility and comprehension: } \\
\text { 1) Intelligibility level: a measurement of students' words and utterances } \\
\text { recognition toward speech intelligibility } \\
\text { 2) Comprehensibility level: a measurement of students' meaning } \\
\text { understanding toward speech comprehensibility } \\
\text { 4. The receptive accommodation: } \\
\text { 1) Compare different phonological features of varieties of English } \\
\text { 2) Complete assignments } \\
\text { 3) Discuss and share ideas together } \\
\text { 4) Read a listening script for comprehension to focus on phonological features }\end{array}$ \\
\hline $\begin{array}{l}\quad \text { Course components } \\
\text { The course components were designed } \\
\text { and developed based on the five terms: } \\
\text { 1. Course objectives } \\
\text { 2. Course contents } \\
\text { 3. Media and materials } \\
\text { 4. Teaching strategies } \\
\text { 5. Learning activities } \\
\text { (Dick et al., 2001; Gagné et al., 2005; } \\
\text { Morrison et al., 2011) }\end{array}$ & $\begin{array}{l}\text { 1. Course objectives: } \\
\text { 1) Recognizing words and utterances toward varieties of English } \\
\text { 2) Understanding meanings of words and utterances toward varieties of } \\
\text { English } \\
\text { 2. Course contents: } \\
\text { 1) Varieties of English (Chinese English, Indonesian English, Singaporean } \\
\text { English, and Philippine English) } \\
\text { 2) ELF phonological features (consonant replacement, p, t, k unaspirated } \\
\text { effect, consonant cluster simplification, vowel length contrast, and specific } \\
\text { word stress) } \\
\text { 3. Media and materials } \\
\text { 1) www.myenglishvoice.com } \\
\text { 2) www.dialectsarchive.com } \\
\text { 3) www.youtube.com } \\
\text { 4. Teaching strategies: } \\
\text { 1) Pre-listening } \\
\text { 2) While-listening } \\
\text { 3) Post-listening } \\
\text { 5. Learning activities: } \\
\text { 1) Classroom activity(group work, pair work, and class discussion) } \\
\text { 2) Listening journal: extra work (Galloway \& Rose, 2014) } \\
\text { 3) Guest speaker invitation: communication practice (Ates, Eslai, \&Wright } \\
\text { 2015) }\end{array}$ \\
\hline
\end{tabular}

Figure 2. The World Englishes Instructional Model

\section{Discussion and Conclusions}

This study developed the WEs instructional model to enhance students' listening comprehension of different varieties of English. Two parts of the instructional model development included analysis of student needs and 
evaluation by experts. Three experts who specialized in English language, curriculum, and instruction evaluated the quality of the model in terms of the consistency of its components and the appropriateness of the component descriptions. This WEs instructional model employed theoretical concepts and instructional procedures and was practical and effective for improving the students' English listening comprehension. The model was systematically constructed using factors related to instruction such as students' needs to support model development.

Development of the WEs instructional model included theoretical concepts, while specific information regarding students' needs analysis was also considered. This model was systematically processed step by step, and each of the phases was relevant to the others. When constructing an instructional model, an analysis of students' needs is essential for teachers to consider when determining instructional gaps, problems, and needs to maximize efficiency. Morrison et al. (2011) suggested that needs analysis referred to identifying gaps and problems as part of the instructional solution. The process should begin by identifying the problems and the needs as a tool for designers based on relevant contexts.

Moreover, based on consideration of both students and context, Dick et al. (2001) identified that it is necessary for instructional design. The designer should analyze students' proficiencies, purposes, preferences, and attitudes to promote effective instruction. Seargeant (2012) noted that educators should weigh up and balance factors and contexts to suit universal validity, and design English instruction appropriately based on the principles of English teaching and learning in international contexts for communicative purposes. The factors and contexts were divided into two sets as (a) practical concerns and (b) ideological concerns related to what should be taught in the classroom and the wider society outside class. Thus, development of appropriate instructions should consider students' proficiencies and communicative purposes relevant to the teaching contexts.

This study paid attention to the WEs concept relevant to English use as a lingua franca (ELF). The English models were selected to suit the contexts appropriately. Yano's cylindrical model relates to English use in current situations (Jenkins, 2015). The model identifies English democratically to all regions including the Asia Pacific zone. The specific characteristic of this model is that the model represents the mutual comprehensibility of varieties of English and places equal emphasis on all varieties of English as independent and undistinguished (Yano, 2009). For that reason, based on communicative context and purpose, the selection of WEs models should be initially analyzed and synthesized to prepare students to communicate internationally with English users in real situations. Kirkpatrick and Sussex (2012) considered that the linguistic goals of English language teaching and learning should be fundamentally redefined based on native norms instead of focusing only on traditional second language acquisition.

Therefore, in this study, an instructional model was developed to enhance listening comprehension by exposing students to varieties of English. Students gained more listening comprehension of different varieties of English, and also improved their tolerance and flexibility with respect to English variation. Ates et al. (2015), Chang (2015), and Lu and Buripakdi (2020) indicated that implementing the WEs concepts into an English course could increase students' positive views, recognition, tolerance, and awareness toward English diversity. While, Cheng (2018) and Kim (2017) suggested that exposure to varieties of English in the real world is essential to facilitate students' listening comprehension in accommodating unfamiliar English accents.

\section{Recommendations}

The WEs instructional model is different from traditional models in EFL and second language acquisition contexts because today English is used as a lingua franca. The proposed model does not aim to replace native norms but rather add varieties of English to enrich students' listening comprehension in an ELF context. The model was developed to provide students with opportunities through exposure to varieties of English. Students gained more listening comprehension of different varieties of English and also improved their familiarity, tolerance, and flexibility with respect to English language diversity.

Future studies will adapt the ideas and concepts presented here to design and develop an instructional model to enhance students' listening comprehension. The selection of WEs models should be initially analyzed and synthesized to prepare students to communicate internationally with English users in real situations. To determine which varieties of English should be selected, based on specific contexts of different countries, further studies should consider the statistics and numbers of English speakers (who use English for traveling, work and business) and students' communicative purposes in English use as targets for communicating and working with in the future.

To design and develop instruction to suit the teaching context and students' communicative purposes, teachers or course designers should consider a balance of English use both inside and outside the classroom to decide which 
varieties of English and skills need to be taught in class, and the appropriate varieties of English and skills that students need to learn and use outside class. Further studies should also add speaking skills to expand the interaction. A guest speaker presents a practical activity that allows students to enhance both their listening and speaking skills to prepare for communicating with English speakers in the future.

\section{References}

Ates, B., Eslami, Z., \& Wright, K. L. (2015). Incorporating world Englishes into undergraduate ESL education courses. World Englishes, 10, 485-501. https://doi.org/10.1111/weng.12149

Boonsuk, Y., \& Ambele, E. A. (2021). Towards integrating lingua franca in Thai EFL: Insights from Thai tertiary learners. International Journal of Instruction, 14(3), 17-38. https://doi.org/10.29333/iji.2021.1432a

Chang, S. Y. (2015). Toward World Englishes writing: Is it idealism in the introductory composition class? (Doctoral dissertation). Purdue University, West Lafayette, Indiana, United States.

Cheng, Y. L. (2018). Unfamiliar accented English negatively affects EFL listening comprehension: It helps to be a more able accent mimic. J. Psycholinguist Res., 47(4), 899-911. https://doi.org/10.1007/s10936-018-9562-y

Cogo, A. (2012). English as a lingua franca: concepts, use, and implications. ELT Journal, 66(1), 97-105. https://doi.org/10.1093/elt/ccr069

Crystal, D. (1988). The English language. London: Penguin Books.

Darasawnag, P., Reinders H., \& Water, A. (2015). Innovation in language teaching: The Thai context. In P. Darasawang \& H. Reinders (Eds.), Innovation in language learning and teaching, The case of Thailand (pp. 1-14). London: Palgrave Macmillan. https://doi.org/10.1057/9781137449757

Dawilai, S. (2017). Problem-based blended learning: An integrated approach to enhance creative writing in English as a foreign language (Doctoral dissertation). Mae Fah Luang University, Thailand.

Dick, W., Carey, L., \& Carey, J. O. (2001). The systematic design of instruction. South Florida: Longman.

Dick, W., Carey, L., \& Carey, J. O. (2009). The systematic design of instruction (8th ed.). United Kingdom: Pearson Press.

Dröschel, Y. (2011). Lingua franca English: The role of simplification and transfer. Switzerland: Peter Lang. https://doi.org/10.3726/978-3-0351-0213-0

Fang, F. G., \& Ren, W. (2018). Developing students' awareness of Global Englishes. ELT Journal, 72(4), 384-394. https://doi.org/10.1093/elt/ccy012

Field, J. (2008). Listening in the language classroom. United Kingdom: Cambridge University Press.

Fraenkel, J. R., \& Wallen, N. E. (2003). How to design and evaluate research in education. New York: McGraw-Hill.

Gagné, R. M., Wager, W. W., Golas, K. C., \& Keller, J. M. (2005). Principles of instructional design (5th ed.). Thomson Learning. https://doi.org/10.1002/pfi.4140440211

Galloway, N., \& Rose, H. (2014). Using listening journals to raise awareness of Global Englishes in ELT. ELT Journal, 68(4), 386-396. https://doi.org/10.1093/elt/ccu021

Graddol, D. (2006). English next. United Kingdom: The British Council.

Harrison, A. (1983). A language testing handbook. New York: Macmillan.

Jenkins, J. (2000). The phonology of English as an international language. United Kingdom: Oxford University Press.

Jenkins, J. (2015). Global Englishes: A resource book for students (3rd ed.). London: Routledge.

Kachru, B. (1985). Standards, codification and sociolinguistic realism: The English language in the outer circle. In R. Quirk \& H. Widdowson (Eds.), English in the world: Teaching and learning the language and literatures (pp. 11-36). Cambridge, UK: Cambridge University Press.

Kachru, B. (1992). Model for non-native Englishes. In B. B. Kachru (Ed.), The other tongue: English across cultures (pp. 48-69). University of Illinois Press.

Kang, O. (2010). ESL Learners' Attitudes toward Pronunciation Instruction and Varieties of English. In J. Levis \& K. LeVelle (Eds.), Proceeding of the 1st Pronunciation in Second Language Learning and Teaching Conference (pp. 105-118). Iowa State University.

Kim, S. (2017). Effects of listeners' communicative experiences in Thai English on the intelligibility of Thai English. English Teaching, 72(3), 69-90. 
Kirkpatrick, A. (2007). World Englishes: Implication for international communication and English language teaching. United Kingdom: Cambridge University Press.

Kirkpatrick, A., \& Sussex, R. (2012). English as an International Language in Asia: Implication for language education. Switzerland: Springer. https://doi.org/10.1007/978-94-007-4578-0

Kongkerd, W. (2013). Teaching English in the era of English used as a lingua franca in Thailand. Executive Journal, 33(4), 3-12.

Lu, H., \& Buripakdi, A. (2020). Effects of global Englishes-informed pedagogy in raising Chinese university students' global Englishes awareness. PASAA, 60, 97-133.

Matsuda, A. (2003a). Incorporating world Englishes in teaching English as an international language. TESOL Quarterly, 37(4), 719-729. https://doi.org/10.2307/3588220

Matsuda, A. (2003b). The ownership of English in Japanese secondary schools. World Englishes, 22(4), 483-496. https://doi.org/10.1111/j.1467-971X.2003.00314.x

McArthur, T. (1998). The English languages. United Kingdom: Cambridge University Press. https://doi.org/10.1017/9780511621048

Modiano, M. (1999). International English in the global village. English Today, 15(2), 22-28. https://doi.org/10.1017/S026607840001083X

Morrison, K., Ross, S. M., Kalman, H. K., \& Kemp, J. E. (2011). Designing effective instruction (6th ed.). New York: Wiley.

Nelson, C. L. (2011). Intelligibility in world Englishes: Theory and Application (1st ed.). Routledge. https://doi.org/10.4324/9780203832578

Pederson, R. (2012). Representation, globalization, and the native speakers: Dialectics of language, ideology, and power. In K. Sung \& R. Pederson (Eds.), Critical ELT practice in Asia (pp. 1-22). Switzerland: Sense Publishers. https://doi.org/10.1007/978-94-6091-797-4_1

Piamsai, C. (2017). Aninvestigation of Thai learners' needs of English language use for intensive English course development. Passa Paritat Journal, 32, 63-97.

Rampton, B. (1990). Displacing the "native speaker": Expertise, affiliation and inheritance. ELT Journal, 44(2), 97-101. https://doi.org/10.1093/eltj/44.2.97

Rost, M. (2002). Teaching and researching listening. South Florida: Longman.

Seargeant, P. (2012). Exploring world Englishes: Language in a global context. Routledge. https://doi.org/10.4324/9780203115510

Seidlhofer, B. (2002). Habeas corpus and divide et impera: "Global English" and applied linguistics. In K. Spelman Miller \& P. Thompson (Eds.), Unity and diversity in language use (pp. 198-217). Continuum.

Smith, L. E., \& Nelson, C. L. (1985). International intelligibility of English: Directions and resources. World Englishes, 4(3), 333-342. https://doi.org/10.1111/j.1467-971X.1985.tb00423.x

Srisa-ard, B. (2002). Introduction to research (7th ed.). Bangkok: Suweeriyasarn.

Sung, C. C. M. (2015). Implementing a global Englishes component in a university English course in Hong Kong. English Today, 31(4), 42-49. https://doi.org/10.1017/S0266078415000383

Todd, W. R. (2006). The myth of the native speaker as a model of English proficiency. rEFLections, 8, 1-7.

Walker, R. (2010). Teaching the pronunciation of English as a lingua franca. Oxford University Press.

Walker, R. (2015). The globalisation of English: teaching the pronunciation of ELF. Modern English teacher, 24(4), 44-46. Retrieved from https://www.modernenglishteacher.com

White, A. R., Treenate, D., Kiatgungwalgrai, A., Somnuk, R., \& Chaloemchatvarakorn, K. (2016). The effects of accent familiarity on English as a foreign language students' word recognition and comprehension of the English language. UTK Research Journal, 10(2), 21-30.

Yano, Y. (2009). English as an international lingua franca: from societal to individual. World Englishes, 28(2), 246-255. https://doi.org/10.1111/j.1467-971X.2009.01587.x

\section{Copyrights}

Copyright for this article is retained by the author(s), with first publication rights granted to the journal.

This is an open-access article distributed under the terms and conditions of the Creative Commons Attribution license (http://creativecommons.org/licenses/by/4.0/). 